\title{
From Indigeneity to Economic Liberation
}

In July 2015, Pope Francis visited Bolivia. During his three-day stay, he repeated the message of his pastoral encyclical calling for a new global ecological ethic linking care for the earth-"our common home"-with care for the poor (Vatican 2015). Observers expected his message would have important echoes with Bolivia's indigenous president, Evo Morales, who has achieved international attention for his left-leaning economic policies, his advocacy for Bolivia's majority indigenous population, and his activism about global climate change. As I have described in previous chapters, since Morales's election, Bolivia has become a site of global inspiration for the Left. Bolivia's new 2009 constitution, with its revolutionary focus on decolonization and vivir bien, or living well, has sparked the imagination of people across the world.

That spark was tangible at the Global Meeting of Social Movements in the lowland city of Santa Cruz, Bolivia. I joined thousands of delegates from across Latin America who came together to greet the pope and to discuss the Vatican's broad themes for social change: Madre Tierra, Techo, y Trabajo (Mother Earth, Housing, and Work). As the tropical rains pounded on the roof of the coliseum, people waved colorful banners from across the region illustrating the agendas of their groups. The participants gave rousing speeches about the efforts of social movements to end poverty and defend their lands against the depredations of transnational corporations. "We are one single river," declared an indigenous woman from Canada, "oppressed, colonized, and tortured." Over and over the speakers cried: "We are fighting one common enemy: global capitalism!!!"

President Morales gave the final speech of the afternoon. Standing against a background of huge posters of global peacemakers, like Mahatma Gandhi, Nelson 
Mandela, and Bolivia's Domitila Barrios de Chungara, ${ }^{1}$ Morales waved to the cheering crowd. "We coincide strongly with the pope on political and social economy," he said. "What can we do with capitalist system? The work now, with the Catholic Church and other churches, is to think about natural resources and basic services. There is plenty of money, it is just badly distributed." Describing Bolivia's "rich experience" with nationalizing its natural gas resources, he explained that Bolivia now has huge national reserves, and as a result, its GDP has tripled. "How the economic system has improved here!" he cried. "This is the result of the struggles of popular movements. And now we are working for economic, political, and technological liberation. ¡Viva Bolivia, Jallalla ${ }^{2}$ Papa Francisco!”

Morales's speech is notable as much for what it leaves out as what it includes. In contrast to the speeches from his early years that I have described in previous chapters, where he argued that indigenous values would save Mother Earth, here he focuses on economic development as the solution to Bolivia's-and by extension the world's-problems. "Economic liberation" is a new euphemism for what scholars call "progressive extractivism" (Gudynas 2010): a national development model based on the extraction and exportation of natural resources on the global market, paired with redistribution of profits to the poor. I argue here that this has become a powerful new consensus in plurinational Bolivia, building on and, in part, replacing previous "revolutionary" discourses of indigeneity, decolonization, and global climate change. In this chapter, I show how indigeneity, once considered the site of ontological alternatives to capitalism, is now rearticulated to global capitalism under a new rubric of economic liberation.

What does this shift mean for indigenous communities? What do decolonization and plurinationalism mean to political activists at the local level, given this shifting terrain? To what extent does indigeneity still serve as a site of politics in the Rancièrian sense after ten years of the MAS state? I examine these questions from the vantage points of three communities: a marginal Aymara neighborhood in the highland city of El Alto, where residents are aiming for middleclass status in the booming economy; and two urban Guaraní communities in lowland Santa Cruz, where struggles over jobs and environmental justice appear to be taking precedence over indigenous identity. In these very differently situated communities, local actors have very different answers to these questions, depending upon their ethnic identification, their economic situations, and their relations to land and markets. In some of the communities I describe, community members hold tightly to their identities as indigenous and continue to make claims on the state to ensure their rights to territory and local self-government. In others, especially the urban communities, ethnic identities appear to be giving way, at least, in some contexts, to larger questions of development and economic well-being. 


\section{THE NEW DEVELOPMENTALISM}

There is little doubt that a conjuncture of forces in the 199os led to important forms of resistance across the country and created the political space for the formulation of revolutionary alternatives. Many scholars hoped that Bolivia would lead the world into a post-neoliberal moment (see Escobar 2010). Far from being a post-neoliberal or post-capitalist reality, however, what we see in Bolivia today is a new form of developmentalism based on resource extractivism, industrialization, and commercial agriculture-precisely what the new plurinational Bolivia was supposed to transform. During the TIPNIS controversy, the MAS government adopted a compelling discourse linking economic development and decolonization. In 2011, the government's approach to the protests, and especially its violent attack on the marchers, were roundly rebuked by the Bolivian public. But Bolivians paid little attention to the 2012 march, even when military police aimed water cannons at women marchers in La Paz. What had changed? During the intervening year, the government began a powerful campaign painting the TIPNIS protesters as backward savages who were creating obstacles to national development. As we saw in chapter 5, Vice President Álvaro García Linera’s book Geopolítica de la Amazonía (García Linera 2012b) articulated the ways in which lowland peoples have been exploited by transnational corporations and lowland elites, contending that the MAS development model would reclaim control of the region and use its resources to redistribute wealth to the poorest people. This ideological argument was bolstered by showcase public works and co-optation of opposition. In many indigenous communities in the TIPNIS region, the government distributed goods and services, including schoolbooks, outboard motors, and foodstuffs. In the highly contested consultation process carried out by the government over the following year, TIPNIS community members were asked, not if they wanted the highway, but if they wanted development. Unsurprisingly, a majority of those who participated said yes.

In July 2015, I visited one of the most visible spokespeople for the 2011 TIPNIS march, Justa Cabrera, a Guaraní woman in her fifties. Doña Justa lives in a small community on the periphery of Santa Cruz. I have known her for almost twenty years, since my first years of fieldwork with the Capitanía Zona Cruz, the Guaraní organization bringing together over twenty communities of Guaranís who migrated to the urban zone in the 1970s. When I first met her in 1996, she was the leader of her small community, and the director of land and territory issues for the Capitanía. Her husband was a member of the Equipo Técnico Zonal, a group of young Guaranís who served as technical advisers to the organization's leader. I documented the work of the Equipo and the Capitania in my first book (Postero 2007a) and have stayed in touch with them and with Justa over the intervening years. She served in a number of roles in the regional and national indigenous 
movement, always as an outspoken militant for indigenous causes. By 2010, Justa was president of the national indigenous women's organization, CENAMIB, which had its office in the compound of CIDOB, the national indigenous organization. I checked in with her every few years when I returned to Santa Cruz, visiting her at her office and hearing about the work she was doing to advance women's rights. She worked with European NGOs, local Church groups, and the national government to find funding for workshops and development projects. She had also traveled widely and was invited to international workshops and conferences. When the TIPNIS struggle began, Justa participated by gathering funds to keep the marchers fed. She gained national and international attention speaking to media about the suffering women marchers and their children endured. She bitterly opposed not only the TIPNIS highway but the MAS government. In a newspaper interview, she said that Evo Morales had become a capataz, an overseer for the transnational corporations, linking him to the evils of past forced labor systems that had enslaved her people (La Cl@se 2011). As described in chapter 5, the second TIPNIS march came to a disastrous end, and with little support, the marchers returned to Santa Cruz to regroup. In 2012, I met with Justa in the city's central plaza, where the CIDOB leaders had pitched tents to make their plight known to the public. Their headquarters had been taken over by MAS supporters, and their struggle appeared at an end. Justa was distraught, and told me about her own harrowing experiences during the takeover, when the "intruders" pushed her to the ground and pulled her hair.

Now, three years later, she and her husband Gregorio are firm supporters of the MAS. As we walked through their quiet village, past the traditional mud and thatch homes under shady trees, she pointed out an open lot. "Here is where the government has promised to build a new coliseum," she said, "and here the new school building." Justa explains how President Evo called her to a private meeting in La Paz the year before, and asked her to support his government. In exchange, he offered her a housing project of one hundred new homes for two of the villages in her area and promised to buy land for five hundred more homes for families without land. Then, in a dazzling show for the media, Evo himself appeared in her village, flying in on a helicopter to make these promises public. In exchange, she declared herself a supporter of the MAS and the president in his 2014 reelection bid.

Naturally, she has been the subject of enormous critique and speculation as a result. This, say many Guaraní, is just how Evo does it: he buys off the vocal leaders, silencing them with obras (public works). "This is egoismo [egotism, or selfishness]," they say, using a term that in Spanish criticizes those who act in their own interests rather than those of the larger community, implying also that the person is corrupt, receiving personal benefits or bribes. "They have divided us, and this is the mechanism," said one Guaraní friend. Used this way, the term egoismo both serves to "out" individuals who do not act within the broader logic of the collective 
and shows envy of individuals who are skillful at negotiating the clientelist logic of the new developmental state. Justa and Gregorio have another, very different perspective, and they explained their pragmatic decision to work with the MAS thus:

After the [2012] march, and the [2014] elections [in which Morales was reelected], we analyzed the situation and said: Do we continue to confront them? Do we just keep marching? No, we need a new process, because to confront them now will take another twenty years. We decided instead to enter the government. The other option was to keep marching, with all our organizations divided. ... Of course, once inside the MAS government, there are still a lot of fights, many interests. But who has more capacity to fight corruption? Them or us? So we say: Who is the dueño [owner] of this process of change? Who marched? We have spent twenty years working for these opportunities, like those coming from the nationalization of the natural resources. Why hasn't [the benefit of] all that arrived here for us?

Justa and Gregorio are not alone. All across the country, former opponents of the MAS "han subdio al tren" (have gotten on the train), voting for and working with the MAS in order to channel funds to their communities. And throughout the country, there is tangible evidence of these public works: shiny school buildings, sports complexes, potable water systems, and modular viviendas (private family houses). Signs with Morales's face frame these works as proof of the process of change at work. Evo Cumple, the signs say: Evo fulfills. As the rest of this chapter makes clear, I am not criticizing these pragmatic decisions. Most of the people I interviewed are happy that the government is funding these important local projects. Rather, my goal here is to point out the way the government's policies and practices have created a new sphere for local organizing-one that focuses on infrastructure, development, and reaping the benefits of natural resource extraction instead of decolonization and indigenous rights.

For the government, the focus on redistribution of profits from extraction has meant wide popular approval: Morales won his third election in 2014, with 60 percent of the vote, (although he did not win a referendum to change the constitution to allow him to run for president again). This popularity allowed the government to formulate a new national development plan, called the Agenda Patriótica 2025 (Patriotic Agenda for 2025) (Bolivia 2013). In it, the government describes how it hopes to make Bolivia a "sovereign and dignified" country. Its agenda is based on thirteen pillars, starting with eradicating poverty, providing basic services, and making sure that all Bolivians have health care, education, and sports facilities. The plan calls for a diversified economy to make this possible. Mining and hydrocarbons will continue to figure largely in the picture, and the country will continue to move towards nationalization, industrialization, and commercialization of these strategic resources. But Bolivia will move beyond the "colonial dependence" on these sectors to develop important new sources of income. First, it will become 
a major exporter of energy, drawing on its hydroelectric potential as well as its renewable energy capacities. Second, it will become a producer and exporter of food products, converting artisanal farming into mechanized, irrigated, and technologically advanced systems. This is part of a larger push for "food sovereignty," aimed at ensuring Bolivians' food security by means of a massive industrialization of the production of food and the exploitation of forest products and other natural resources (ibid.).

The plan continues to frame the country's overall goals in terms of vivir bien, and protection of the Madre Tierra, but analysts argue this is really window dressing for a modernist capitalist development project based on continued natural resource extraction and a radical expansion of the agricultural frontier. Alcides Pinto Vadilla of Fundación Tierra, a Bolivian NGO focused on agrarian policies, points out that the plan links Bolivian producers ever more to the global market and to commodity prices established globally (personal communication, July 27 , 2015). Moreover, critics fear these plans have dangerous implications for the environment and climate change. For example, in 2014, Morales declared that by 2025, the country should increase the number of hectares in production from the current level of 3.5 million hectares to 10 million (El Diario 2014; Urioste 2015). To accomplish this, the government has recently agreed that people can deforest up to twenty hectares without any permission from the Forest Ministry as long as they use the land to produce food. This is a radical departure from previous regulations, and promises a rapid deforestation of fragile Amazonian lands. Perhaps more shocking, in 2015, the government passed a decree authorizing oil exploration within Protected Areas (like national parks and nature preserves) and indigenous territories ( $\mathrm{La}$ Razón 2015). Morales also declared that prior consultation with indigenous people was unnecessary and a "waste of time" (Erbol 2015).

These changes belie much of the language and revolutionary character of the new constitution, yet there has been very little opposition to them. This is the result of meeting the interests of some sectors and silencing of others. The campesino (peasant farmer) sector is broadly supportive of this developmentalist agenda. Indigenous Andean peasants tend to have small plots of land, and they produce for both national and international markets. They are linked to urban centers through kinship-based commercial networks. The coca-growing sector in the tropics and temperate Yungas areas and the large migrant farming population in the eastern lowlands are also dependent on marketing their products and support new government investments in highways linking their zones to larger centers. (Their support for the proposed TIPNIS highway was illustrative of their interests.) All these producers welcome the renewed focus on agricultural production and benefit from government gas price subsidies and credit programs. As Alessandra Pellegrini Calderón (2016) points out in her new work on Yungueño coca growers, these rural farmers are an "emerging peasant middle class with increasingly entrepreneurial, 
market-based activities in both production and commerce." Rather than seeing themselves as indigenous peoples, they situate themselves as both peasants and as a socially upward moving group (2016: 149).

Urban indigenous peoples also appear to benefit in both indirect and direct ways. As described above, the economy has grown enormously as a result of the nationalization of the hydrocarbon sector, and the redistribution of the government's share of royalties and gas rents has been invested at the local and departmental (state) level across the country. The large emphasis on public works means growth in the construction industry and growing indigenous employment in the municipal and departmental governments. As Nico Tassi and his collaborators have shown, this has also led to a booming import and export business linking Bolivia to Brazil, Chile, and China, producing a new sector: the Aymara global merchant (Tassi et al. 2013). For many urban residents, the hope of economic prosperity appears to drive political support for Morales.

Even the lowlands elites have seemed content in recent years. In the initial years of the MAS administration, mestizo elites and commercial farmers in the lowland region felt threatened by the MAS economic agenda to radically redistribute lands and natural resource revenues to the poor (Fabricant and Postero 2013). Their opposition to the MAS was especially salient during the Constituent Assembly, when they organized massive public protests across the country and even a "prefectural coup" to push for departmental autonomy. Many of their demands lost force, however, after the passage of the new constitution, which instituted a form of both indigenous and departmental autonomy. But most important, by 2012, the government had made an economic pact with this sector, ensuring the ability of regional agribusinesses to continue to grow. Morales hopes that Bolivia will soon become a regional leader in soy production, further contributing to the booming lowland economy. This is a goal that lowland elites share.

While many critics see this new developmentalism as a betrayal of the promises of an indigenous alternative, others see it as an inevitable result of class interests. Alcides Pinto Vadilla of Fundación Tierra puts it this way:

\footnotetext{
Many see Evo as a traitor. I don't see him that way. I see him as who he is, a leader of a campesino union. Where did we get the idea that the campesinos were revolutionary? They are allied with capitalism when the economy is good, and revolutionary when it is not. So Evo is just serving their interests. His proposals are to help his sector, they are not transformative ... [The MAS has] generated a new mechanism for accumulating wealth for their followers. They have made a pact with the lowland productive sectors, but they have not allowed them to govern. They let them [the rich lowland business sector] do their business, but they say, don't tell us how to spend the resources.
}

This pact with the business sector, then, allows money to flow, keeps the former opposition happy, and promotes a strong, market-based economy. In exchange 
for almost complete control over the political institutions, the government keeps loosening environmental regulations, making extraction and commercial farming easier and more profitable.

But what about indigenous people in the lowlands? While many lowland indigenous people also live in urban or peri-urban communities, a large proportion live in rural areas, relying on forms of production and subsistence requiring large areas of land. As noted in the Introduction, since the 1990s, lowland groups' traditional livelihood strategies have received state recognition and many have received collectively titled territories (although many demands are still in process). They have been at the forefront of political struggles for self-determination and autonomy, seeking to control their own lands according to their customs and culture. They were a central voice in the Pacto Unidad, the group of indigenous organizations that articulated much of the language of indigenous rights and vivir bien that makes the new constitution so revolutionary. Their demands have been consistently different from those of the campesino sector described above (Rivera Cusicanqui 2015). They have defended their territories, their forms of life, and their right to make decisions about development, consistently articulating a strong concern for the environment, and represented themselves as caretakers of the Earth. Thus, the current government policies of economic development based on extractivism and the expansion of the agricultural frontier are a substantial challenge for them and their abilities to move towards the forms of revolutionary political transformation the new constitution promised.

A crucial step in the Morales government's ability to push through its development plan was the silencing of critical voices from the lowlands. CIDOB, the lowlands indigenous organization, had been a central protagonist in the push for indigenous rights for nearly thirty years, and its leaders had organized and spearheaded the TIPNIS marches. I have described the post-TIPNIS takeover of CIDOB in chapter 5, giving eyewitness accounts of how a parallel organization took control of the CIDOB headquarters, backed by tear gas and government police. Its leader, Melva Hurtado, from the Beni region, made clear from the beginning that this new CIDOB supported "brother" Evo Morales, and that they just wanted to work for development in their communities (La Jornada 2012). In exchange, the new CIDOB received over a million dollars in funding from the MAS government. With it, they transformed the headquarters, building a modern four-story office complex with air-conditioning and apartments for the organization's leaders. They administered production projects in indigenous communities friendly to the government, providing tractors for improvement of pasture and wells for cattle and craft and textile projects for women. In her public appearances, Melva Hurtado faithfully echoed the lines from the government playbook. In August 2015, I traveled to the town of Guarayo, in the eastern part of the country to observe the Guarayo indigenous organization's twenty-eighth anniversary. 
Melva was an honored guest at the ceremony. Speaking from the dais to the crowd of residents and visitors braving the suffocating tropical heat, she described the projects CIDOB had sponsored there. "We are here to work for the development of all," she told the crowd. "We are searching for peace, for unity among indigenous brothers, and to construct the patria grande [the great country]. . . We have left politics behind; we are looking for development. . . . We must work together to move forward, without egoismo, without divisions" (emphasis added).

Thus, one of the most important oppositional voices, CIDOB, is now firmly in the MAS camp. They did not utter any public protest to the 2015 decrees opening up indigenous territories and protected areas to exploration. To the contrary, when I asked CIDOB's Environmental and Climate Change Officer, Rafael Álvarez, about that, he denied that the MAS government had any responsibility. "The government is not causing any damage; it is the foreigners, like the United States. Bolivia is the victim of climate change!" All that is left, he says, is adaptation to the damages, learning how to live with the environmental changes and moving forward. "What else can we do? The industrialized countries just go ahead [polluting] and we just keep conserving our forests. Should we just stay in poverty while everyone else lives well? No! We need development" (personal communication, July 28, 2015). But, like Melva, he too gave voice to the fears of egoism and corruption that circulate in tandem with this developmentalist discourse. A few months previously, leaders of the national indigenous fund, the Fondo Indígena, had been accused of diverting millions of dollars intended for local indigenous development projects. Álvarez denied any wrongdoing on the part of CIDOB, pointing instead to the supposed wrongdoings of the prior president, who had led the TIPNIS marches. Only a few months later, however, Melva Hurtado herself was jailed for improprieties as part of the Fondo Indígena scandal. That case is still pending as of this writing.

This leaves the other traditional voice of opposition, the NGOs. They, too, are under threat, as the government launched a campaign to discredit and silence them. In June 2015, Morales issued a statement that any NGOs that object to the government plans to explore for natural resources in forest reserves or indigenous territories would be subject to being thrown out of the country. He said that he would not allow NGOs who were the pawns of foreign interests to prejudice Bolivia's interests. "We have the obligation to explore what we have in our territory. ... Of course it is our obligation to take care of our environment, but we can't be the park rangers for the industrialized countries" (Yunasby 2015). This created an enormous uproar among NGOs, and made many of them extremely nervous. Several told me privately they felt very vulnerable and unable to exercise what they saw as their role as civil society watchdogs. "Who can speak for the environment now?" one NGO worker asked. "They have co-opted the indigenous organizations and threatened us." 
Indigenous communities negotiate this new conjuncture from very different perspectives. In the rest of this chapter and in chapter 7 , I turn to examples of local indigenous community responses. Of course, these communities cannot stand in for all indigenous people in Bolivia. Rather, they offer a view of the diversity of interests and strategies we see among local peoples. They also represent different lengths of fieldwork on my part. My description of the reactions of urban Aymara is the result of a few weeks of fieldwork in 2015, based mostly on interviews. While I have lived and worked in La Paz and El Alto off and on since 1995, I have not carried out long-term fieldwork in El Alto. Thus, the story I relate is descriptive, although it squares with longer-term data from other researchers and NGO workers. The case studies in the lowlands, on the other hand, are the result of many years of research and participant observation. I have been working in Bella Flor and El Futuro, ${ }^{3}$ neighboring Guaraní communities in peri-urban Santa Cruz, for twenty years, returning every year or two since 1995. My first book is based upon my research with the federation of Guaraní villages these two communities belong to, and I lived off and on in Bella Flor during 1997-99. I first visited Charagua, the subject of chapter 7, in 1997, accompanying Guaraní friends from Santa Cruz to an assembly of the national Guaraní federation, the Asamblea del Pueblo Guaraní (APG). Since 2010, I have carried out three periods of field research there, most recently in 2015, observing the autonomy process as it unfolded. My previous work with the Guaranís of Santa Cruz opened many doors for me in Charagua. Several of my closest Guaraní friends and informants from Bella Flor are, in fact, originally from Charagua, and I have been able to use their kin networks to establish connections. The fact that I wrote a book about Zona Cruz also makes a difference. It is a helpful entrée in most local communities. When I hand out copies of the Spanish translation of my book, people understand I have been collaborating with Guaranís for many years and are more likely to be willing to discuss their lives with me.

\section{URBAN AYMARAS: “CON PLATA VIVIMOS" \\ (WITH MONEY, WE LIVE)}

In July 2015, I visited the community of Rio Negro, an urban barrio on the outskirts of El Alto. I had previously met the community's leader, Gonzalo León, to talk about how urban Aymara communities were experiencing Evo Morales's "indigenous state." Over the past few years, commentators and scholars had been describing the rise of a new indigenous middle class. The excellent work of Nico Tassi and his colleagues, for instance, has shown how Aymara merchants leveraged kin relations and Aymara logics of circulation to build enormous amounts of capital and create transnational circuits from Chile through Bolivia to China (Tassi et al. 2013). This has allowed the new Aymara entrepreneurs to develop a 


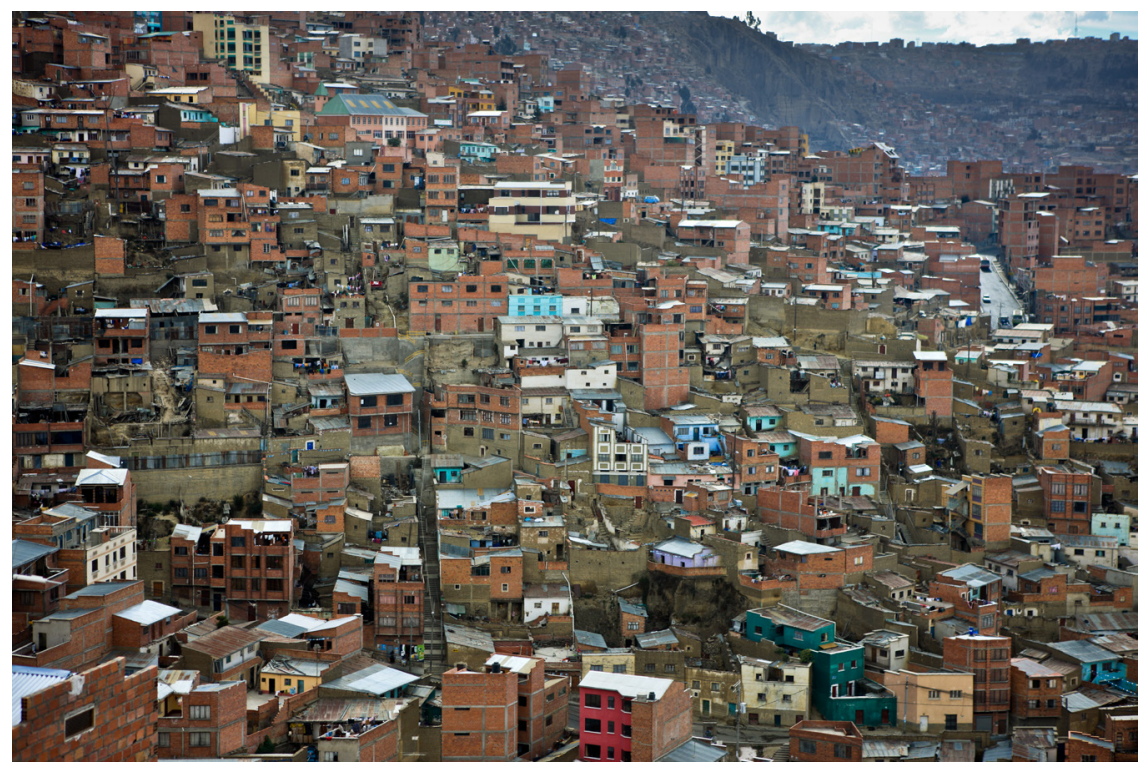

FIGURE 15. Middle-class neighborhoods in La Paz. Credit: Cliff Helles. https://creative commons.org/licenses/by-sa/3.o.

distinctive form of conspicuous consumption that has be garnering international attention. For instance, the "Nuevo-Tiwanaku" style of the Aymara architect Freddy Mamani Silvestre's multicolored cholets (a witty combination of cholos-urban Andean indigenous-and "chalets"), which have sprung up all over the city of El Alto (La Nación 2015), has been lauded by a portfolio in the New Yorker (Granser and Thurman, 2015). I was interested to learn if this new affluence and sense of prosperity are also felt in the marginal communities. What did decolonization and indigeneity mean in these contexts?

Gonzalo and I met in a coffee shop in downtown La Paz, introduced by a sociolologist who had worked in his community for some time. Over the course of several hours, Gonzalo described his life trajectory and the struggles he and his neighbors have waged to build their community from a vacant field on the windy plains they took over in 2009 to the growing urban barrio it is today. Gonzalo's trajectory was similar to those of many in his neighborhood, he said. He was born in the provinces, in the department of La Paz, and came to the city at the age of fifteen to find work. After his military service, he went to Argentina, where he worked for a decade in construction and clothing factories. He returned home with a little capital to try to build a life. He bought a minivan and began working as a chauffeur for tourists, as well as transporting merchandise from the country to the city. $\mathrm{He}$ 
met his wife, also a migrant from the countryside, and together they found a small lot in Rio Negro. First, they put up a wall around their lot and built a tiny oneroom house. Gradually, they built up their assets, buying several more minibuses, which he rented to family members. With loans from family and friends, Gonzalo then began importing cars from Chile. With profits from this business, he bought a larger truck, and his wife began a small store on their lot. First, she sold groceries, and then opened a second, adjoining store selling bricks and cement-a smart move in the rapidly growing neighborhood. On the weekends, they added onto their house, brick by brick and room by room. I asked if he considered himself to be middle-class now. Well, not yet, he said, but "I have a house and two stores, five kids all in school. I hope they will be educated. Soon, we will build a salon de fiestas, a venue for people to rent for parties. And my biggest hope is to gain a fixed job, as a chauffeur or in an office."

Gonzalo's answer raises the question of how to measure the middle class. Even though only 17 percent of Bolivians meet the World Bank's criterion of earning at least \$10 per day, 53 percent consider themselves middle-class, according to a 2013 Informe Latinobarómetro survey (Los Tiempos 2013), and the figure is even higher in El Alto, where fully 70 percent see themselves as middle-class (World Bank 2013). As my discussion with Gonzalo makes clear, identifying as middleclass is a subjective call: "self-positioning in terms of class is not an absolute and objective measurement of a quantity of goods, but rather a relative measure of the position of each person in society. It has to do with the power that each person has to belong to a social group. The poor are not poor only because they are poor in goods, but poor in terms of power" (Los Tiempos 2013). In Bolivia, it is argued, the election of Morales to the presidency has given many people a sense of power they never had before, and this translates into a sense of economic well-being (ibid.). Is this so? Or is it the reverse?

Gonzalo made it clear that the money flowing from the government is the reason why many Alteños support Morales:

NGP: So what do you think about the discourse of Evo about decolonization? How about all the work at the Constituent Assembly, and the ideas of vivir bien, etc.?

G: Look, this has served the people, because the transnational companies had 80 percent of the gas money and the state only had 20 percent. So the Constituent Assembly changed all that, now it is 18 percent to the TNCs and the rest for the country. And this has generated a lot of money! . . Ha habido mucho recurso! [There have been many resources!]

Here Gonzalo makes a common mistake, suggesting that it was the Constituent Assembly that nationalized the hydrocarbon sector. In fact, President Morales accomplished this through an executive decree. However, this mistake demonstrates a 
larger "truth": for most poor people, decolonization is not about colonial legacies or the rights of indigenous peoples, but rather the just distribution of the profits from national development. As I explained in previous chapters, the government has argued that its national development agenda based on extractivism and redistribution is, in fact, a form of decolonization. Gonzalo's explanation appears to embrace that view. Yet he lamented the fact that these funds have been badly administered by the government and make for substantial corruption. He explained that government redistribution through public works has produced new kinds of patronage:

Evo has a hold on the social movements. It is through the popular organizations that he gets support. The leaders go meet with Evo, and he gives them obras (public works). ... Evo has the power, and so they can say: Evo is going to come to give us this obra, so we all have to be there, and applaud.... So that makes it really hard for other political parties to compete. For example, the Coliseo Cerrado [the public coliseum in El Alto] cost two million bolivianos. Without nationalization we wouldn't have had this. That is where the money comes from. So we all say thank you, Evo, and thanks to the nationalization of natural resources. And in the process, we are campaigning for Evo.

The next week, I met Gonzalo in his community. I made my way on the windy dirt lanes to the new sports complex, where the junta vecinal (JV; neighborhood association) was holding its weekly meeting. Nearly a hundred people sat on plastic chairs, bundled up in blankets, listening to debates about how to best push the city to bring plumbing out to the community. A constant stream of people approached the head table, bringing their monthly cuotas, or fees, and their house booklets to be stamped. Each household must send a representative to get the stamp and pay the two-boliviano (about 40 U.S. cents) fee, or be fined. The treasurer carried out a careful accounting with each resident. As the meeting wrapped up, I talked to a group of neighbors about how El Alto was changing.

Luís, a thin man in his fifties, shyly told me he and his family were part of the land takeover that had formed the community. They were there since this place was nothing but dirt and bushes. They put up a little tent to claim ownership of the land, and have been struggling ever since to get basic services like water, electricity, and sewage. An older man, Samuel, said: "We Aymara are very organized, as you can see. We all pay our cuotas, and if we have to, we protest." Pointing to the sports complex, he said, "this center is the result of our protest, marches, and strikes. We fought for it." But they all agreed with the signs I had seen throughout the city saying, "Nuestra Cuidad Está Cambiando" (Our city is changing). Luís explained: "Life is better in Bolivia now with Evo. Before, all our money was going out of the country to the USA and the transnationals. There was no money and no jobs."

Samuel chimed in: "Yes, now there are jobs. We came here from the provinces to educate our kids. In the provinces, there were no schools, no jobs. And we like 
to have fun just like you in the U.S.! . . Before Evo, we couldn't get in to those jobs, to those schools. The elite saw us as black, only people like you, white, could go to schools. Now it is all the same, we are all equal. He has opened the doors to all this. And this is really important! Our kids can become professionals." So, I asked, are you all middle-class? José, a wiry man with his coat buttoned up to his nose, nodded enthusiastically. "Yes! Now I have lots of work, I have built a house here, and my three kids are in school. I expect them to be professionals and that is the point. That's why we came. There are now jobs and money, and that's why we support Evo. We have jobs."

This positive perspective echoed with what I had heard all over the city. From scholars to government officials to taxi drivers, people explained Morales's popularity as a result of the booming economy. One Aymara woman I interviewed in La Paz explained that the economy didn't benefit everyone equally, but things were better. Doña Patricia and her family own a jewelry store where they fabricate and sell the ornate gold-plated jewelry cholas wear for dress-up occasions like weddings and baptisms. She showed me the huge new synthetic gems that local wholesalers had imported from China. "It is the importers who are making all the money," she complained, "not us merchants." Her intuitions are reflected in the economic data: China is exporting large amounts of goods to Bolivia. Alejandra Saravia López and Adam Rua Quiroga (2015) show that Chinese imports (notably, mining machinery, motorcycles, cell phones, and herbicides) far outweigh Bolivian exports to China, resulting in a significant trade deficit (10). They argue this trend has consequences for manufacturers in Bolivia, as they are losing their sales position within both the national and international market. This "call[s] into question the survival of a large number of small and medium-sized enterprises" (10-11). Carlos Arze Vargas (2016) makes a compelling argument that the massive increase in imports from China, and the large proportion of people working in the informal market-the majority in sales of these imported goods-means that Bolivia is increasingly unable to sustain itself by producing its own food or consumer goods. Yet, as Patricia the jeweler shows, this has not kept people from supporting the president.

She lamented the corruption in the local juntas vecinales, where local leaders were skimming money off the new urban infrastructure projects. But she said, of course, she voted for Morales. "Who else???" she asked, as if that were beyond debate.

NGP: So the president talks about being indigenous . . . Do you identify as indigenous or Aymara?

P: We are Aymara, of course. Indios somos, pero. [Of course, we are Indians].

NGP: So when he talks about the new plurinational state, or descolonization, what does that mean to you? Or, what is decolonization? 
A: Hmmm, well, it means that things are different from before. [pause] But, what does it mean, then? Really, it is all politics.

NGP: Politics?

P: Yes, politics, you know, a matter for the political parties.

NGP: Doesn't it mean anything for you?

A: Well, no. I am not against the government, though.

NGP: Why?

A: Pues, ha habido mucha plata [There has been a lot of money].

NGP: You mean there is more money flowing now?

A: Yes. You know my mother and grandmother didn't ever know money. They didn't touch it, they lived on haciendas in the countryside. There was a lot of oppression then, no? But now, we have money, they have money. Con plata vivimos [With money, we live].

In Rio Negro, local leaders like Gonzalo have taken advantage of the new political and economic conjuncture to get the city to build the sports complex a few years ago, and now a new community nursery school is being built, with some foreign foundation funding and some support from the city. They took me to tour the construction project, displaying the new classrooms and kitchen. Later I spoke with Johnny Huanca, an Aymara migrant who runs a lumber mill and hardware store in the neighborhood. We sat in his store, surrounded by rolls of wire, PVC pipe, and buckets of screws, as he proudly recounted his trajectory. Like Gonzalo, he and his wife began with a small lot and a small artisanal lumber mill serving the neighbors. Now his business moves $\$ 200,000$ worth of lumber per month from the Beni region in the Amazonian lowlands to fuel the construction boom in El Alto. He has just finished building two additional floors above his businesses, adding three bedrooms, a living room, kitchen, and study.

NGP: So do you consider yourself middle-class?

JH: Yes. We have transformed ourselves from what our parents' lives were in the campo. But I still identify as Aymara. We have a house, stores, three kids in school. No car yet, but I want to get one soon to drive the kids around in.

NGP: Is this the result of the MAS? Do you support the MAS?

$\mathrm{JH}$ : Yes, but there is good and bad. The bad thing is that we have to pay a lot of taxes now. ... The good is that thanks to Evo, our people are now working in offices, they use the internet-there are cholitas in polleras in government offices! This was never the case before. We weren't allowed to go up to those places. I remember as a kid with my grandmother hearing white people say, here come those indios. That never leaves you, it is inside you. But now it is different, Evo has opened the doors. 
In Rio Negro, then, the most important effect of the "indigenous state" is that it has "opened the doors" of both political and economic opportunity to the Aymara and poor residents. With money flowing from the state to the city and through the social movements, people sense that the Morales government has benefited "the people" instead of transnational companies. While they all make clear they identify as Aymara, these residents' sense of decolonization does not reflect a simple notion of indigenous rights or any notion of indigeneity being an alternative to capitalism. Rather, it echoes the government's discourse of economic liberation: for them, liberation implies economic well-being and everyone getting an equal piece of the pie. They see themselves rising in class status and a brighter future for their children as professionals.

\section{BELLA FLOR AND EL FUTURO: COMMUNITY DEVELOPMENT STRUGGLES}

Let us move now across the country, to the outskirts of the lowland capital of Santa Cruz, to the communities of Bella Flor and El Futuro. These barrios came into being in the 1960s, when Guaraní indigenous families moved to the region to work in the sugarcane harvest. Guaraní families moved from the Chaco region in the south to what was then open land some twenty kilometers outside the city of Santa Cruz, building three separate communities on a large parcel of 500 hectares. Through the agrarian reform, they received title to the parcel, and over the following years, more families settled there. When I did my fieldwork there in 1995-98, the three villages were organized as indigenous Guaraní communities, with leaders elected in assemblies according to Guaraní traditions (see Postero 2007a). They were part of the larger regional Guaraní federation, the Capitanía Zona Cruz, which represented twenty-five communities around the Santa Cruz region. During that period, the Guaranís of Zona Cruz were engaging with the provisions of the new Law of Popular Participation, one of the key provisions of Bolivia's neoliberal multicultural reforms. Through this law, indigenous communities were recognized by the state, and incorporated into state governance through usos y costumbres, or traditional customs. This meant that local politics was organized around ethnic categories: the indigenous organization, called the capitania, was the official representative to the municipal government and participated in budget and development decisions. I observed as my Guaraní friends learned how to register their organizations legally, understand municipal politics, and make demands on behalf of their communities. In Santa Cruz, this new form of citizenship produced minimal results for the Guaranís because they remained marginalized minorities. In other regions, where indigenous people were more numerous, the reforms enabled indigenous organizations to win local political offices such as city council and mayoral seats. The Charagua case discussed in chapter 7 is an example of this. 
For the Guaranís of Bella Flor and El Futuro, the multicultural years were a boom period: they got grants from foreign aid to form and strengthen their indigenous institutions; many young people got scholarships for training and some went to college; and local leaders were plugged in directly to city funding sources. Development projects aimed at helping the indigenous poor targeted them, helping urban women produce Guaraní textiles and crafts. In the following years, however, their circumstances changed radically. The city overtook their rural villages, and migrants from the highlands poured into Santa Cruz. Many Guaranís sold their shares in the original parcel, causing enormous disputes in the villages. That dispute eventually resolved, giving most of the Guaranís title to some individual lots. The result is astonishing: the original Guaraní villages are no longer recognizable, swallowed up by a huge urbanización, or urban housing development. Each of these two communities, which had about sixty Guaraní families in 1996, now has over twenty thousand residents, the great majority of whom are Andean migrants from the highlands. Once quiet rural communities of mud-and-thatch Guaraní houses, now they are bustling, peri-urban working- and middle-class neighborhoods.

I have watched this process closely over the years, as I have remained close friends with the family with whom I lived in Bella Flor during my fieldwork, the Taperas. They remain in Bella Flor. Don Jesús, the patriarch, now in his late sixties, is an evangelical pastor, and his wife Susana, although quite ill, continues to run the household. Their children are all adults now, and the house is filled with grandchildren, especially on the weekends. Their daughter Mónica, who received a scholarship to train as a journalist, works at a radio station dedicated to indigenous culture and politics. She and her small family live with their parents in Bella Flor. Mónica's brother, Samuel, my closest friend, has finished law school, thanks to a scholarship, and works as a consultant for the Capitanía. He also teaches Guaraní. He and his family live nearby in a rented apartment in El Futuro. Thanks to the sale of several lots they received in the settlement, the Taperas have rebuilt their home. Now they have a brick construction with three bedrooms. It is not fancy-only one of the rooms has a tiled floor, the others are still packed-down dirt-but they have electricity, running water, and a separate bathroom outside. Susana sells groceries and cold soda from a small storefront building facing onto the street, attracting customers from the busy health post across from them. They have friendly relations with kolla (people from the highlands) neighbors interspersed throughout their barrio.

Like the residents of Rio Negro described in the previous section, the Taperas and many of their Guaraní neighbors are moving from poverty to middle-class status. They have urban jobs, stable houses, and their children are being educated. They, too, have benefited from infrastructure investments by the state and the city: a large sports complex draws people to the central plaza of Bella Flor, and a new 
secundaria (high school) has just been built in El Futuro. Yet, they have very different opinions about Morales, the "indigenous state," and decolonization. First, it is important to situate their communities for the reader. As I have described in previous chapters, Santa Cruz was the center of opposition to Morales. Its whitemestizo political class mounted a strong pushback to the Constituent Assembly and organized a successful regional autonomy movement. Santa Cruz continues to be led by opposition parties at both the departmental and city levels. (This has begun to change recently, however. In the 2014 presidential elections, the MAS won Santa Cruz.)

Perhaps more important, however, many Guaranís have continued to identify with the lowland indigenous agenda, and this has pitted them against the Morales government. The TIPNIS struggle described in chapter 5 was a central watershed for many. The leadership of the Capitanía Zona Cruz participated in the 2011 TIPNIS march, and the local communities supported them with money and material support. Mónica Tapera was on her way to the march when the Chaparina police intervention happened, and so she and others organized a hunger strike in the central plaza of Santa Cruz that mobilized public opposition to Morales. She spent much of the next few years reporting on the TIPNIS case and continues to work with former CIDOB leaders to press their case through the Defensor del Pueblo (Bolivia's national ombudsman) and on to the Inter American Human Rights Court. For Mónica and Samuel, watching the way the government handled the TIPNIS issue made it clear that all the language in the constitution about indigenous rights means nothing in practice. They were deeply disappointed and hurt. The next year, 2012, Samuel Tapera led a contingent of Zona Cruz Guaranís to defend the CIDOB office from takeover by the MAS-allied sector. They camped out in the compound for a week, but without material support, were unable to continue. Shortly afterward, the current leaders stormed the headquarters with police and strongmen. One of the original CZX Equipo Técnico, Rosana Moreno, was living at CIDOB at the time and had just given birth to twins a few days before. I met with her a few weeks after the event, and she described the hellish experience of having to pack up her children and flee through the melee and tear gas. Beaten and insulted by the opposing group, she says she will never forgive the Morales government for its treason. For these Guaranís, decolonization is a joke, a "cynical" discourse that Morales uses to justify his power. They lament the way the MAS state has co-opted indigenous organizations, reducing everything to money and obras. Mónica Tapera explained:

The government has taken over all the possible spaces, CIDOB, the electoral council, the judicial sector. There are no spaces left now. And now everything is about money. They say, "We will give you this if you support us." And the indigenous groups have no choice, they don't say anything, because todos tenemos cola [literally, we all have tails, meaning, we are all guilty or bought off]. Look how many indigenous leaders 
have stopped making any real demands, and now they are all funcionarios con pegas [they all have government jobs]. ;Tan barato se vende!! [How cheaply they sell themselves!]

So for these urban Guaranís, their identity as indigenous peoples remains a central part of their identity and a central lens from which they evaluate their lives. In Bella Flor, they have had to struggle to maintain political power, given the demographic change in the barrio. Their kolla neighbors control the school board and have argued that the capitanía should cede its position with the city to a junta vecinal (JV). Yet the Guaraní leader, Diego Eloy, supported by his community, pushes back. I spoke to him one afternoon at his house. He is a taxi driver, and his three sons were washing his car before he began his shift in the city. The neat house and yard reflect his strong sense of dignity and his aspirations for his family and neighbors. "We can't lose our traditions," he says. "We are the only barrio left where we Guaraní are the majority. In El Futuro, the kollas have already stomped on everything. But here, we Guaranís still rule [mandan].” He refuses to let them run the show, he says, but he has had to collaborate with them. They have organized with the city to get the plaza refurbished, create a green space, get some new schoolrooms, and so on. His biggest project, though, has been accomplished as the capitanía. Everyone agreed that the worst problem facing the community was youth gangs, pandillas, who hung out in the streets at night, smoking marijuana, drinking, fighting, and robbing people. Don Diego finally intervened, organizing with local police to create a youth patrol made up of Guaraní and kolla youth. The police donated a vehicle that had been seized in a drug-forfeiture case, and the new patrol circulated at night monitoring the barrio and calling the police when necessary. This was so successful that the police are beginning a new program in which these youth cadets are getting formal training that will (hopefully) lead them to jobs with the police. Don Diego says that with this success, he has shown the kollas that the Guaranís are still a force to be reckoned with.

In El Futuro, a few kilometers away, however, things are very different. There, the Guaraní are working with their kolla neighbors to confront a much bigger problem: a huge toxic landfill on their borders. The landfill is run by the city of Santa Cruz, and it was set up long after the Guaranís arrived. In the intervening years, it has grown precipitously, mirroring the explosive growth of the city. It is a horrible stinking mess, venting methane gases and leaking sewage onto surrounding roads and lands. In El Futuro, depending on wind direction, an acrid burning smell fills the neighborhood, stinging people's eyes and causing respiratory illnesses. When it rains, sewage flows into people's yards and pollutes their water. Over the years, surrounding communities have mounted repeated demands that the landfill be closed. Time after time, the city has agreed to some of the conditions of the protesters and negotiated an end to the protests. An independent audit contracted by the Santa Cruz state government confirmed that the area was 
contaminated and causing health risks to the residents (CAVE 2015). Yet the city keeps postponing the closing, pending finding another site for a new landfill.

In 2015, Sandra Chávez, the segunda capitana, or second in command of the Guaraní capitanía of El Futuro decided to start working on this problem with her kolla neighbors. She invited me to her house to explain. We sat in the front yard, according to Guaraní custom, and she poured a drink she had made from chia seeds - to try to be healthy, she said. Her sister, head of the women's organization, joined us, as did her neighbor Patti, and Jorge, a highland migrant from Cochabamba. Sandra explained that the previous leaders had not wanted to work with the kollas, but she disagreed. "Why discriminate?" she argued. "We are not pure Guaranís here, and we have important problems to face. We have to work together." For her, the health issues they faced as neighbors overcame any ethnic difference. With Jorge and other kolla neighbors, they began organizing the barrio, and then in March 2015, they carried out a massive blockade of the landfill. Over three hundred people took over the entrance, preventing the entrance of waste disposal and garbage trucks from the city. They lasted five days, surrounded by police with all the pressure of the mayor's office and public disapproval. As garbage piled up, the neighbors held on. The mayor came to negotiate, but they had signed an agreement ahead of time that they would not be bought off like the leaders of previous protests. Eventually, they were dislodged and did not gain any major concessions. However, they felt happy with their efforts. The press had been supportive, and a big article ran in the local paper saying the landfill should be closed (El Deber 2015). Their blockade had forced the release of the independent audit, which supported their position. They are not naïve enough to think this alone will force the city's hand, but they do have hopes that the evidence will push public opinion forward.

Like Sandra, their highland neighbor Jorge felt that it was worth overcoming the tensions between ethnic groups. He privileged their shared class struggles, born from the precarious situations in which they lived. Patti, Sandra's neighbor made that especially clear:

When we held the blockade, they worried that people in the city would get sick [because garbage was not being picked up]. But what about us getting sick? They say: why did you buy out there next to the landfill? But we are poor, we have nowhere else to go. The people in the richer parts of the city-their rights are getting protected. What about our rights? Y por el hecho de ser pobre, ¿no tenemos derechos? [Just because we are poor, don't we have rights?]

Jorge agreed:

Our rights have to be respected, these are human rights at stake. With the laws that Evo has made, he says he values the environment, worries about contamination, prioritizes health. But this is a discourse. They don't respect human rights, or is it that they don't think we are humans? 
For these neighbors, then, organizing around ethnicity sometimes gives way to more basic pragmatic issues of justice. In the case of El Futuro, as Patti suggested, "this was a civic movement, demanding rights of life and health." Their ethnic differences have not disappeared, as Don Diego of Bella Flor makes clear, but in contrast to the multicultural era, in this period, working together for basic forms of community development appears to be ever more necessary and important.

\section{CONCLUSION}

This chapter has focused on the lived experiences of some of the many indigenous communities in Bolivia, to consider the effects of a decade of MAS policy and practice. There are large differences between the circumstances and economies facing these communities, and their political trajectories are even more opposed. The highland migrants to El Alto I describe are part of the core constituency of the MAS party, sharing ethnic identity and history with their "brother Evo." The Guaranís on the outskirts of Santa Cruz come from a different trajectory: the lowland indigenous organizations that came into being in the 1990s, formed part of the Pacto Undidad at the Constituent Assembly, but broke from the MAS as a result of the TIPNIS controversy. Having an indigenous president and an indigenous state has meant very different things to these communities.

I suggest that in the contemporary period, indigeneity appears to be a less salient site of organizing as the dominant government discourse shifts to one of economic liberation and development. I do not wish to be misunderstood here. For each of the people I presented in this chapter, their ethnic identity-as Aymara or Guaraní-remains central to their lives, kin relations, and community struggles. As we saw in the case of El Futuro, the forms of political representation hard-won in the 1990 are not easily relinquished. Yet more and more, in both El Alto and the Guaraní communities, other issues and other forms of doing politics are emerging. Indigeneity was the site of emancipatory politics in the multicultural $1990 \mathrm{~s}$ and into the Morales era, giving people a way of seeing themselves, and expressing their demands for inclusion and self-government. The struggles I document in this chapter show that indigeneity no longer serves as a sufficient basis for such politics. Of course, class and race/ethnicity have always been intersecting categories, as I showed in the Introduction. They continue to be so today. I suggest that, as the Morales government consolidated its hold on the state in large part by justifying its government through discourses of indigeneity and decolonization, those discourses lost some of their emancipatory power, remaining important in the symbolic dimension, but losing importance in the realm of local politics. As $\mathrm{Pa}$ tricia, the jewelry seller in El Alto put it, "that is a matter for the political parties." 